\title{
The mechanism for the development of public- private partnerships in agriculture (on the example of the Republic of Uzbekistan)
}

\author{
$G G$ Dustmurodov $^{1, *}, I O$ Yunusov $^{1}, U K$ Ahmedov $^{1}, S h M$ Murodov $^{1}$, and $S T$ Iskandarov $^{2}$ \\ ${ }^{1}$ Tashkent institute of irrigation and agricultural mechanization engineers, 39, Kari Niyazov Street, \\ 100000, Toshkent, Uzbekistan \\ ${ }^{2}$ Andijan Institute of Agriculture and Agro Technologies, 1 Oliygokh Street, Kuygan-Yor town, \\ 170600, Andijan region, Andijan district, Uzbekistan
}

\begin{abstract}
Research in this area is very relevant, the mechanism of publicprivate partnership in agriculture is very important, it allows, under mutually beneficial conditions, the state and the private sector to increase the resource base and direct unused resources to the stable development of the agricultural sector. The aim of the article is to study theoretical approaches and substantiate empirical recommendations aimed at improving the mechanism of work of public-private partnerships in agriculture in Uzbekistan, and in general.
\end{abstract}

\section{Introduction}

The Republic of Uzbekistan has a favorable environment for the development of the agricultural sector. Such industries as fruit and vegetable growing, horticulture, viticulture and animal husbandry are developing at an accelerated pace. Special attention is paid to the development of infrastructure for processing agricultural raw materials and preserving manufactured products. At the end of 2019, about 80 thousand farms and 53 thousand dehkan farms, 152 agricultural clusters in fruit and vegetable production, 144 in grain production, and 93 clusters in cotton production were operating in the Republic of Uzbekistan [1].

In the agricultural sector in 2019, 3.543 million people were identified who work in this area (26\% of the total number of employed), of which 1.066 million are officially employed 2.477 million in the informal sector or self-employed. The sale of agricultural products abroad accounts for about $25 \%$ of total export revenues. After analyzing the distribution of the shares of the gross output of the agricultural sector by categories of farms, it was revealed that the highest indicators in all regions of the country are in dekhkan farms. In 2018 , dekhkan farms produced $88.4 \%$ of the total volume of potatoes, $74.3 \%$ of vegetables, $60.8 \%$ of melons and gourds, $62.6 \%$ of fruits and berries, $55 \%$ of grapes, $92.3 \%$ of meat, $95,1 \%$ milk, $52.6 \%$ eggs, $7.4 \%$ fish [2]. The category of farms produces $78.7 \%$ of grain

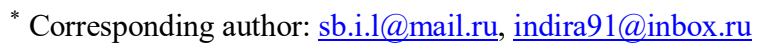


and $96.2 \%$ of harvested raw cotton. Organizations engaged in agricultural activities mainly produce eggs (36\%), fish $(64.1 \%)$, vegetables (18\%). Farms have at their disposal $85.2 \%$ of the sown land, in 2018 they produced $26 \%$ of agricultural products. Dekhkan farms have $11.3 \%$ of the sown land; in 2018 , they produced $71.2 \%$ of the total agricultural production. Organizations engaged in agricultural activities account for $2.8 \%$ of manufactured products [3-5].

Agriculture shows optimistic indicators of development dynamics. At the same time, it is not worth stopping, in order to continue, it is necessary to ensure that additional sources and resources are attracted to the development of agri-food infrastructure, to increase the profitability of agricultural activities, to attract various categories of participants in the agricultural process, from small to large entrepreneurs, including farmers, into the whole production system. focused on internal and external consumption. Achieving this goal is possible due to the intensification of the use of opportunities for communication between the public and private sectors in the format of public-private partnerships, as well as with the involvement of foreign partners. According to the experience of developing countries, public-private partnership has taken a stable place in the development of agriculture, and has proven its practical effectiveness, acquiring the status of an integral element of ensuring food security (Fig. 1).

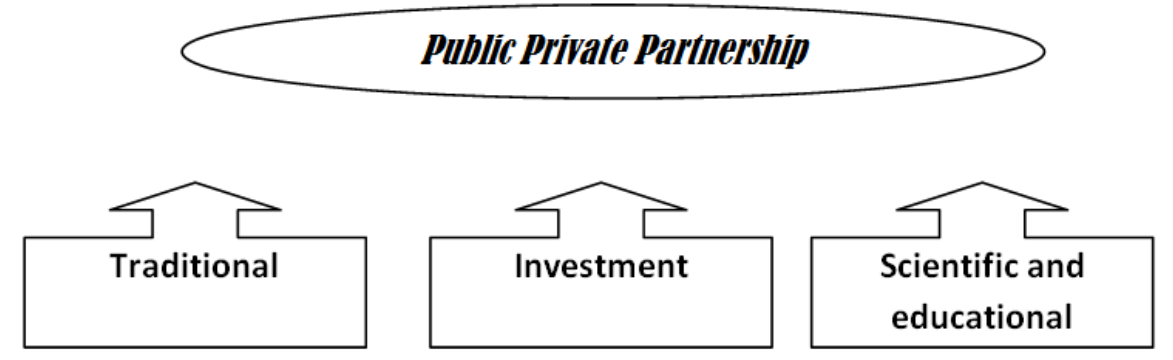

Fig. 1. Forms of cooperation between the state and the private sector.

In everyday life, the concept of "public-private partnership" is gaining great popularity. Public-private partnership implies a merger of the state system and the private sector, the purpose of this merger is the implementation of important projects for the development of strategically important sectors of the economy and the implementation of social services on a large scale of the country.

The structure and mechanism of work of the integration of the state and the business sector have been actively used for a long time and very successfully, it is being improved every year. These countries include Great Britain, France, Germany.

Great Britain carried out the first project in 1981. The UK has used the potential of public-private partnerships to redevelop the London docks. This project was successfully completed and a new Private Finance Initiative (PFI) program was created. The basis of this program was the transfer to the private sector of the functions of financial support for construction (operation, reconstruction, management, etc.) of state-owned production and social facilities.

In France, models were used where the state, in order to attract private investors to public projects, created communities of a mixed economy (Societed'Economie Mixte, SEM), that is, in fact, joint ventures. The enterprises were formed on the condition that the share of the state or other self-government bodies in the total authorized capital would be from 50 to $85 \%$ [6-7].

In Germany, support centers for public-private partnerships are being created, which operate at the federal state and federal level. For the first time, such a center Deutschland 
AG (Partnerschaften Deutschland) was created in 2008, at the federal level. The Center is an independent consulting company run by the federal ministries of finance and the ministry of transport and construction.

\section{Methodology}

The research used general scientific research methods. The mechanism of public-private partnership in modern conditions was studied, an analysis of the definition and essence of the concept of public-private partnership was made, its meaning was clarified as an effective form of implementation of investment activities. All the positive aspects of the implementation of public-private partnership projects for all parties, for the state, the private sector and the country's economy in general, have been systematized.

\section{Result}

Public-private partnership in the field of agriculture is a formalized cooperation between state institutions and the private sector, created for the stable development of the country's agricultural sector, taking into account the following conditions:

- the state should receive any benefit from the implementation of the planned project

- investments and risks must be shared between partners

- all project participants must participate in the implementation of the project at all stages of the project life cycle.

According to the international practice of developing public-private partnerships in the agricultural sector, the state is usually represented by central or regional government bodies, state banks and other financial institutions in the field of agriculture, state-owned companies, and state scientific research and educational institutions.

The private sector of a public-private project can be represented by the following persons: companies engaged in the production of agricultural products, as well as their processing, processing, storage of food products, financial organizations, small and medium-sized enterprises, farmers, producer associations, agricultural cooperatives, and others.

In the area of partnership with the private sector, the state forms a regulatory mechanism in three directions:

1. The state develops a strategy, principles for the interaction of regulating business relations with the social sphere and with public authorities.

2. The state forms the institutional environment for the formation and implementation of partnership projects.

3. The state is engaged in the organization and management of public-private partnerships, develops forms, methods, and mechanisms.

In a public-private partnership, the state usually performs the following tasks:

1. Establishes the need for partnership agreements with private sector structures in certain areas of the economy.

2. Creates proposals and recommendations for public-private partnership projects.

3. Taking into account interests, describes the key features of projects, forms the process of selecting private partners.

4. Gathers a package of necessary documentation for projects, negotiates and concludes an agreement with private partners.

5. The execution of agreements is under the control of the state.

6. Evaluation of the fulfilled conditions of the agreement by the private partner. 
7. Recommendations on termination of the contractual relationship with a private partner under state control.

Public-private partnerships in agriculture are profound. This is a form of cooperation on mutually beneficial terms between the state and the private sector in order to modernize agriculture in the regional and local markets, while the project preparation falls on the private partner, and the share of the risk on the partner who can reduce it.

The priority areas in the formation of public-private partnerships in agricultural production are:

- creation and implementation of new technology platforms;

- wider attraction of private investment can lead to accelerated development of reclamation systems;

- notification of risks and formation of an information and methodological base for insurance of agricultural producers ' risks;

- merging business with education;

- development of various infrastructure on the territory of agriculture and creation of management organizations for them;

- development of transport infrastructure and logistics.

In a public-private partnership, each member has its own benefits. The state has advantages in the form of:

- increase in the economic efficiency of projects due to reduced costs and risks

- efficiency in decision-making;

- access to alternative sources of capital;

- access to innovative technologies;

- implementation of strategic projects at the macro level;

- development of advanced principles of agro-industrial complex enterprise management.

Benefits of public-private partnerships for business:

- reduction of tax liability;

- guarantees from the state;

- free adoption of administrative and economic decisions.

Public-private partnership has a positive effect on the country's economy as a whole:

- the export of agricultural products is developing;

- in the implementation of public-private partnership projects, infrastructure is intensively developed;

- main production assets are updated faster;

- the material and technical base of the agricultural sector increases the speed of development;

- improves the quality of agricultural products;

- increases competitiveness;

- the potential of the raw material base of local processing enterprises is increasing.

Public-private partnership is based on an agreed program, and the program-target management method is taken as the basis.

The program-targeted method of management is relevant all over the world, this method of management combines various management functions such as information, cognitive, predictive, strategic and others. With the target-oriented method of management, a document is taken as a basis, which contains terms, resources, performers, all the necessary information to achieve the goal. Such a program includes an activity planning mechanism, a budgeting mechanism, a consolidation mechanism, and so on.

There are a number of obstacles to the development of public-private partnerships in agriculture: 
- as a rule, private sector participants are not interested in long-term projects, since more private sector participants aim to earn maximum profit in a short time;

- lack of free funds to participate in public-private partnership projects;

- lack of qualified specialists among employees of the agro-industrial complex to work with public private partnership projects;

- lack of practice, experience, which confuses the private sector, and scares them with unexplored risks.

Public-private partnership is used in the implementation of investment programs that are socially oriented in nature, aimed at obtaining greater profits, and above all, creating socioeconomic benefits that affect the life of people and their well-being. It takes into account the creation of additional jobs, the increase in tax revenues to the budget, and the creation of economic benefits that affect the standard of living of the population. As an example, a project based on public-private partnership will bring social and economic benefits, such as improving the quality of roads, integrated public utilities, improving the efficiency of health and education, creating centers of economic activity, and activating the infrastructure of cities and rural areas as a result of attracting investment.

In agriculture, there are problems such as soil fertility and lack of sufficient water resources. The Asian Development Bank estimates that $43 \%$ of Asia's land is not suitable for agriculture, up to $80 \%$ of fresh water is used for irrigation purposes, and $35 \%$ of all finished agricultural products are spoiled or lost.

These indicators indicate that agricultural development is not feasible without proper infrastructure development. Due to the fact that direct investment has a great impact on the development of agriculture, many Asian and European countries began to use the mechanism of public-private partnership in agriculture.

Public-private partnership is the development of the state and the private sphere to solve socially important issues on mutually beneficial terms. In accordance with the Decree of the President of the Republic of Uzbekistan on October 20, 2018, the Agency for the Development of Public-Private Partnerships was created. The tasks of the Agency are to determine a unified public-private partnership policy in the Republic of Uzbekistan, consider new projects, agree on tender documents and agreements on public-private partnership. The Agency for the Development of Public Private Partnerships in Uzbekistan under the Ministry of Finance is developing a public-private partnership structure in conjunction with sectoral ministries and departments, local authorities and other state bodies.

On April 26, 2020, a resolution of the Cabinet of Ministers of the Republic of Uzbekistan "on improving the procedure for implementing public-private partnership projects" [8] was adopted in order To ensure the implementation of a unified state policy in the field of public-private partnership.

New approaches have been assigned in the context of public-private partnership. One of the main supports is the joint work of the state and the private sector. Mechanisms of public-private partnership can be seen in subsidizing loans. Farmers who are studying new business lines and solving import substitution problems, the need for affordable loans is growing accordingly.

Interaction between the state and the private sector benefits not only the state, but also the private sector. The main challenge in the modern economy is to increase production to accelerate the substitution of food imports and improve the competitiveness of local agricultural producers. The state is providing food security, and agribusiness is increasing its place in the domestic and foreign markets. Another very important issue is the development of infrastructure for storage, processing and transportation of agricultural products. If we improve storage facilities and increase processing capacity, we can increase the quantity and quality of food and reduce the price on the food market. 
In the public-private partnership in the agro-industrial complex, there are several areas that can be used separately, or they can be combined.

The common goal of public-private partnerships is the efficient use of land. The solution may be to transfer unused land resources to a concession. For example, the state owns unused infrastructure facilities, while the private sector has transport facilities, elevators, etc., all of this can be jointly used together on the basis of public-private partnership [9-11].

The interaction of the private sector and the state is an effective tool in the creation of various types of integrated formations - agricultural firms, agricultural holdings and Agro clusters. As a result of such interaction, the agrarian vector of the development of the region is being developed and the merger of all production forces into a single chain.

Another engine of innovative development of the country's agriculture can be considered the implementation of projects to create industrial parks. The creation of industrial parks based on public-private partnership will benefit all areas of development. Agricultural processing enterprises can operate on its territory.

Special economic zones are also a special form of public-private partnership. Such models are aimed at creating a favorable investment climate, as well as in the field of agroindustrial production. There are currently more than 22 free economic zones in Uzbekistan [12]. This form of partnership is very promising for the agricultural sector.

The variety of forms of public-private partnership that have already been tested, but are not too common in the agro-industrial complex, opens up great horizons for combining efforts and rational allocation of resources. The solution of successful forms of cooperation allows attracting private investment and ensuring further solution of modern problems of development of the agricultural sector of Uzbekistan.

A significant part of foreign direct investment is aimed at equipping the producers of our Republic with the means to increase the scale of products produced for export and improve their quality. For the period of 2020 , more than $\$ 800$ million of foreign direct investment was allocated for the construction of modern greenhouses, and about $\$ 75$ million was allocated for the construction of new processing and storage facilities for fruit and vegetable products [13-14].

\section{Conclusions}

Having analyzed domestic and foreign experience in developing agricultural infrastructure in the context of food security in the Republic of Uzbekistan, public-private partnership projects should be given great importance. For the development of public-private partnerships and their impact on the development of agriculture, it is necessary to stimulate the development of public-private partnerships in the field of agriculture, including motivating local and foreign private investors.

An important condition for the implementation of project interaction between the state and the private sector in the agricultural sector can be a general analysis from all sides of the "infrastructure readiness" of the industry. The results of the analysis can be used as the basis for a national plan for the infrastructure development of the agricultural sector of Uzbekistan with the inclusion of project proposals that should be actively developed in the local and foreign investment market. In promoting the proposals of public-private partnerships in the field of agriculture, the main emphasis should fall on the fact that Uzbekistan has a huge advantage in the production and export of organic agricultural products.

The National Strategy for the Development of the Agricultural Sector of the Republic of Uzbekistan for 2019-2030 [15-17] provides for measures to develop public-private 
partnerships for the provision of additional services in the agricultural sector, as well as reforming the scientific sphere and industry research organizations.

The Republic of Uzbekistan is at the initial stage of development of conditions for the full development of public-private partnership. The development of public-private partnerships will fully improve the provision of social benefits in all areas. Resources, experience, and other positive aspects of the private sector can ensure rapid implementation in the modernization of socio-economic infrastructure, without imposing large operating costs on the state budget. It is advisable to introduce a public-private partnership system in stages and find an approach that will allow the implementation of new sources of the economy and help in solving strategic socio-economic problems.

\section{References}

1. Altukhov A I, Silaeva L P, Vinnichek L B at al 2016 Methodology and mechanisms for improving the location and specialization of agro-industrial production (Kursk)

2. Decree of the President of the Republic of Uzbekistan dated October 232019 № UP5853 "On approval of the Strategy for the Development of Agriculture of the Republic of Uzbekistan for 2020-2030

3. Nabokov V I, Nekrasov K V 2017 Management of innovative activity of agroindustrial complex organizations in modern conditions Agri-food policy of Russia 1(61) 30-32

4. Kozlova E V 2014 Public-private partnership as a factor in the development of an innovative economy: author. dis. Candidate of economic Sciences (Moscow) 27

5. Agriculture of the Republic of Uzbekistan for January-December 2019 (State Committee of the Republic of Uzbekistan on Statistics)

6. Chukhlomin N V 2011 Evaluation of the effectiveness of public-private partnership in the creation of special economic zones: author. dis. Candidate economic Sciences (Novosibirsk) 20

7. Pankratov A A 2010 Public-private partnership in modern practice: basic theoretical and practical problems (Moscow) 248

8. Resolution Cabinet of ministers of the Republic of Uzbekistan № 259 dated April 26 2020 "On improvement of the $\mathrm{p}[1]$ rocedure for implementation of public-private partnership projects"

9. Varnavsky V G 2012 Management of public-private partnerships abroad Issues of state and municipal management 2 134-147

10. Gafurova G T 2013 Foreign experience in the development of public-private partnership mechanisms Finance and Credit 48(576)

11. Varnavsky V G 2002 Economics, economic theory. Partnership between the state and the private sector: theory and practice (Moscow: Science)

12. Akinina V P, Abasov R G 2013 Public-private partnership as a catalyst for innovation processes Finance and Credit 9 45-50

13. Guidelines on Private Public Partnerships for Infrastructure Development UN Economic Commission for Europe Dec. 2000

14. Shulyatieva G M 2016 Innovations in households as a factor in the development of rural areas Bulletin of Science and Education 1(13) [Electronic resource] Access mode: https://cyberleninka.ru/article/n/innovatsii-v-hozyaystvah-naseleniya-kak-faktorrazvitiya-selskih-territoriy/ (date of access: 05.10.2020) 
15. Ivanova Z A 2014 Public-private partnership in agriculture: general approaches Problems of Economics and Law № 12 110-114

16. Malinovsky A A, et al 2021 Engineering Economics: Decisions and Solutions from Eurasian Perspective. ENGINEERING ECONOMICS WEEK 2020. Lecture Notes in Networks and Systems. 139 283-287 doi: 10.1007/978-3-030-53277-2_33

17. Strielkowski W, et al 2019 Energies 12(7) 1392 doi:10.3390/en12071392 